\title{
Note on Abnormal Flowers in Orchis purpurea, Huds.
}

\author{
BY \\ J. R. MATTHEWS, M.A., \\ Assistant Lecturer in Botany, Birkbeck College, London.
}

With four Figures in the Text.

T $\mathrm{N}_{\mathrm{w}}$ specimens of Orchis purpurea, Huds. gathered in Kent by one of the advanced students at Birkbeck College, several flowers were found to show various abnormalities in structure. A large number of inflorescences were examined, both in the field and in the laboratory, and out of three spikes sixteen flowers were obtained which presented deviations from the ordinary type of conformation.

The main abnormality consisted in an increase in the number of stamens. Orchis purpurea, like the majority of Orchids, develops normally only the anterior stamen of the outer whorl, AI (Fig. I), while the other members, A2, A3, are represented by staminodes in the shape of auricles (Fig. 2). In some of the abnormal flowers the staminodes were replaced by stamens having both pollinia fully developed, so that the flower became triandrous (Fig. 3). In several cases only one staminode was transformed and diandrous flowers resulted, the stamens being either $\mathrm{AI}, \mathrm{A} 2$, or AI, A3. In these diandrous forms the staminode which was not transformed maintained its ordinary position on the side of the column. This would seem to show that the staminodes are potentially stamens,

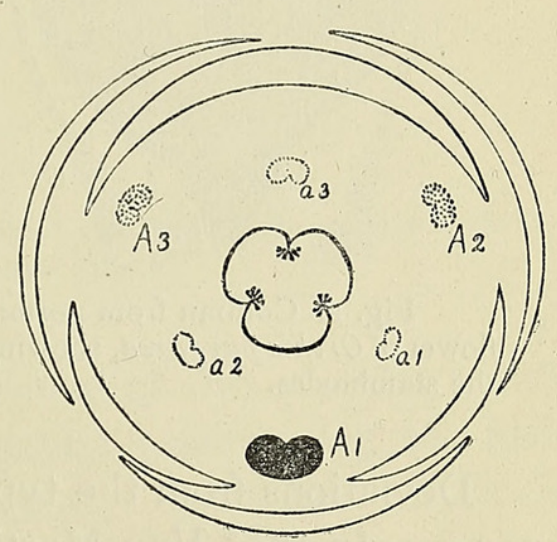

Fig. I. Diagram of Orchis flower. The stamens $\mathrm{A}_{2}, \mathrm{~A} 3$, are represented by staminodes on the side of the column. and their appearance as such in a fertile condition goes pari passu with their disappearance as staminodes. This also means that the additional stamens are not derived from any other normally suppressed members of the androecial whorls. In one case a further departure from the type was observed. The stamens AI, A2, were fertile, and the posterior stamen of the inner whorl $a_{3}$, which is usually completely suppressed, was represented by a pollinium arising

[Annals of Botany, Vo1. XXIX. No. CXIII. January, 19J5.] 
from the mesochil. According to Pfitzer the odd stamen a3 does occasionally appear in abnormal flowers.

These abnormalities in the androecium were not always accompanied by any other malformation in flower structure. Two flowers showing the triandrous condition were otherwise quite normal (Fig. 3). On the other hand, cohesion of the sepals occurred in some, and in many flowers this was observed without, however, any modification in the androecial whorls. In the flower where $a 3$ was represented by a pollinium the labellum was considerably modified. One lateral lobe was scarcely developed, and the middle lobe showed little trace of its usual bifid character.

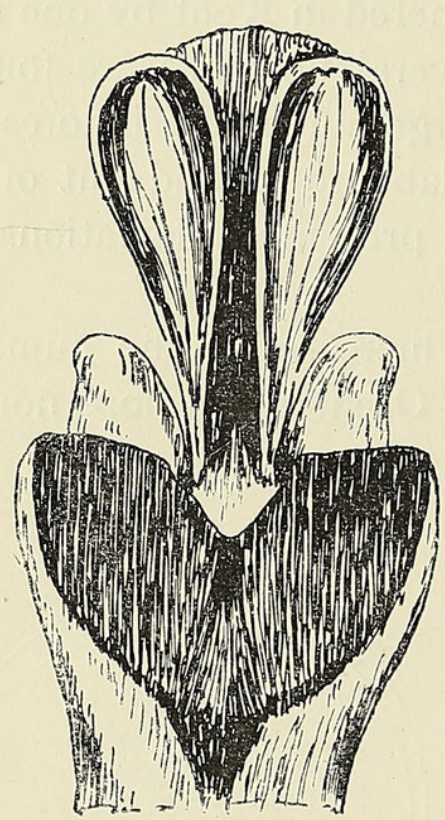

Fig. 2. Column from normal flower of Orchis purpurea, showing the staminodes.

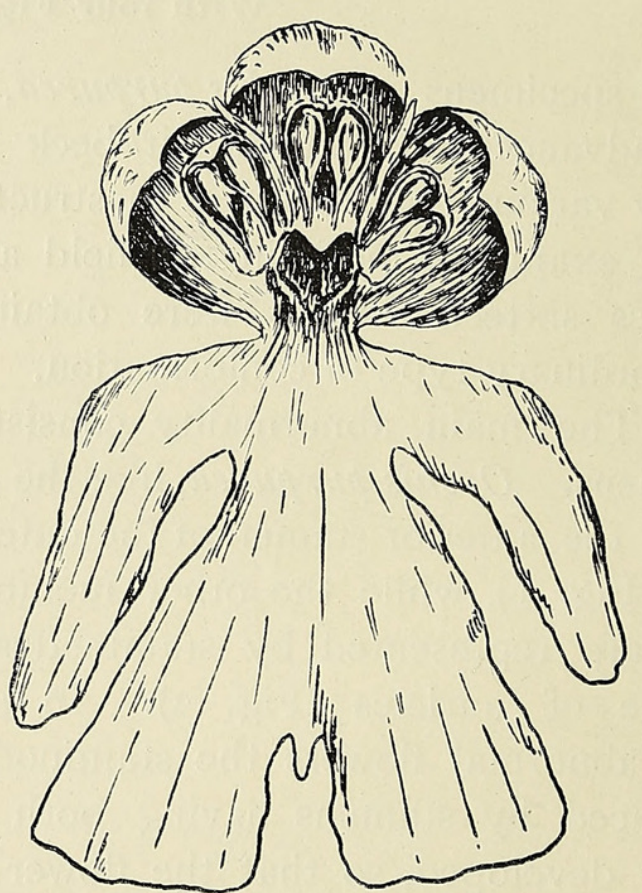

Fig. 3. Triandrous flower; the staminodes appear as fertile stamens.

Deviations from the typical structure in Orchid flowers have long been known. In I825 Von Martius (1) recorded three anthers in Orchis Morio, and adds, ' monstrosa, anth. 3 ! singulae naturaliter conformata'. A hexandrous flower of Orchis militaris, to which $O$. purpurea is a close approach, has been described by Kirschleger (2). Further details of numerous abnormal forms are given by Masters (3), and more recently by Penzig (4). In many of these instances it appears that substitution occurred. The normally suppressed stamens appeared in a petaloid state. In my specimens the stamens were fertile, the tendency being towards a restoration of numerical symmetry.

It is not the purpose of this note to enter into a full discussion regarding the homologies of the Orchid flower. The discussion is well known, and has arisen because of the striking departure from the monocotylous type 
which Orchids make, especially in the androecial and gynaecial whorls. A question that specially interested the earlier workers was whether all the stamens in a more or less complete state of development are confluent with the column, or whether the two lateral members of the outer whorl are incorporated with the labellum. Brown (5) advances the view that the small auricles of Orchis are essentially the same structures as the leaf-like staminodes in Diuris, and therefore form the complement A2, A3, of the outer whorl of stamens. But to this view Brown did not permanently hold. At first he believed the stamens A2, A3, were combined with the labellum. Cruger (6) contends that the labellum is a simple organ and not the union of one petal with two petaloid stamens. According to

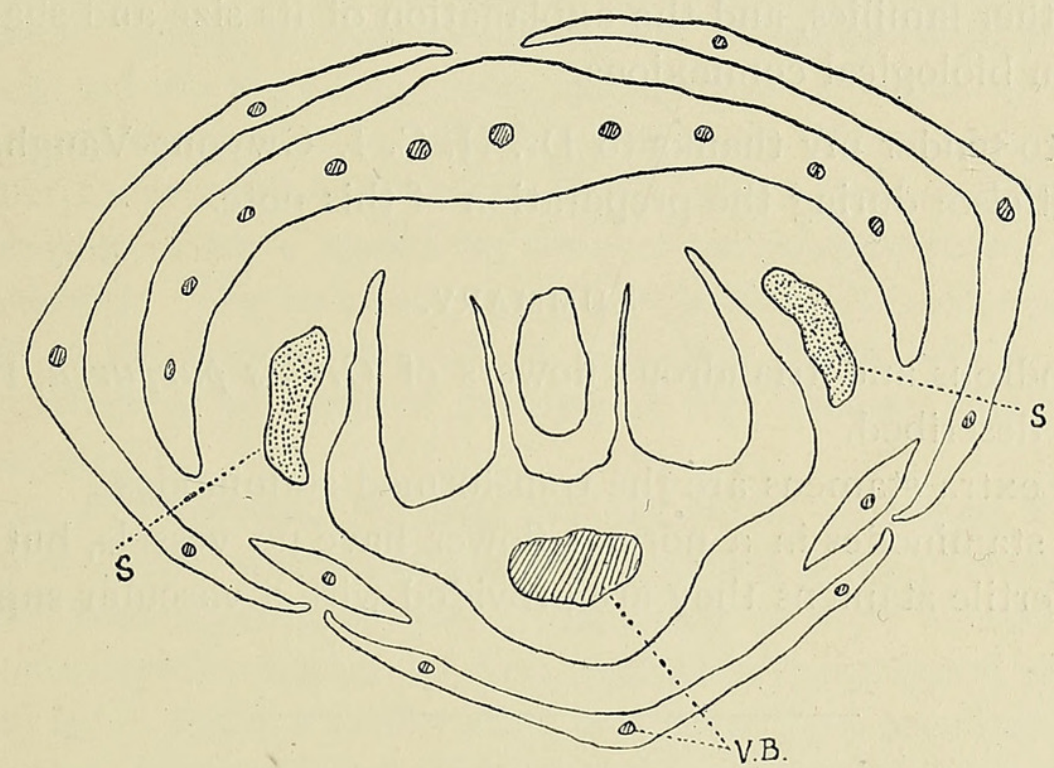

Fig. 4. Transverse section through bud of normal flower where the staminodes are free from the column. S. staminode; v.B. vascular bundle.

Darwin (7), whose views are based on the course of the vascular bundles in the flower, the labellum is a complex structure representing the fusion of the odd petal with the pair of outer stamens. This hypothesis has lost favour in view of the more recent study of floral development by Pfitzer (8). The number and distribution of the vascular bundles in the labellum are a physiological problem, and cannot always be accepted as morphological evidence. In Orchis Darwin found no trace of bundles in the auricles which he believed to represent the stamens of the inner whorl. Nor have I succeeded in tracing vessels to these structures in cases where the flower is normal. They are small and need no special system apart from the large bundle which supplies the column. But when they develop into stamens in such abnormal flowers as have been described, then I find that each is supplied with a vascular strand. As stamens their demand for nutrition is greater than when they remain as staminodes. The 
distribution of bundles, in fact, would seem to be determined by physiological needs.

In the foregoing account I have referred to the auricles or staminodes as the representatives of the stamens A2, A3, for in a transverse section through the bud of a normal flower (Fig. 4) their relative position to the other floral parts indicates that they belong to the outer staminal whorl. I have already mentioned that in the diandrous flowers one of the staminodes remained normal. It is natural to assume, therefore, that in the triandrous condition the extra stamens represent both staminodes transformed, and, like the staminodes in a normal flower, belong to the outer androecial whorl. Thus it seems that the stamens A2, A3, are not associated with the labellum. This structure remains a simple organ whose analogue is to be found in various other families, and the explanation of its size and shape is to be sought for in biological connexions.

I wish to tender my thanks to Dr. H. C. I. Gwynne-Vaughan for kind help and criticism during the preparation of this note.

\section{Summary.}

I. Diandrous and triandrous flowers of Orchis purpurea, Huds. found in Kent are described.

2. The extra stamens are the transformed staminodes.

3. The staminodes in a normal flower have no vessels, but when they develop as fertile stamens they are provided with a vascular supply.

\section{LITERATURE.}

1. Von Martius ('25): Flora, p. 736.

2. Kirschleger, Dr. ('44): Teratologische Notizen. Flora, p. I3I.

3. Masters, M. T. ('69): Vegetable Teratology, p. 380.

4. Penzig, O. ('94): Planzen-Teratologie, Bd. ii, p. 357.

5. Brown, R. ('33): On the Organs and Mode of Fecundation in Orchideae and Asclepiadeae. Trans. Linn. Soc., vol. xvi, p. I3I.

6. Cruger, H. ('65): On the Fecundation of Orchids and their Morphology. Journ. Linn. Soc., vol. viii, p. I 3 I.

7. DARWIN, C. ('77): Fertilisation of Orchids.

8. Pfitzer, E. ('89): Orchidaceae. Engler und Prantl, Die natïrlichen Pflanzenfamilien, ii. Teil, 6. Abt., p. $5^{2}$. 


\section{$2 \mathrm{BHL}$ Biodiversity Heritage Library}

Matthews, J. R. 1915. "Note on abnormal flowers in Orchis purpurea, Huds." Annals of botany 29, 155-158.

https://doi.org/10.1093/oxfordjournals.aob.a089535.

View This Item Online: https://www.biodiversitylibrary.org/item/243629

DOI: https://doi.org/10.1093/oxfordjournals.aob.a089535

Permalink: https://www.biodiversitylibrary.org/partpdf/320056

\section{Holding Institution}

Smithsonian Libraries

\section{Sponsored by}

Biodiversity Heritage Library

\section{Copyright \& Reuse}

Copyright Status: Not in copyright. The BHL knows of no copyright restrictions on this item.

This document was created from content at the Biodiversity Heritage Library, the world's largest open access digital library for biodiversity literature and archives. Visit BHL at https://www.biodiversitylibrary.org. 